\title{
Cocoa Swollen Shoot Disease in Côte D'ivoire: History of Expansion from 2008 to 2016
}

\author{
Romain Aka Aka ${ }^{1}$, Klotioloma Coulibaly ${ }^{1}$, \\ Walet Pierre N'guessan ${ }^{1}$, Koffié Kouakou ${ }^{2}$, \\ Gnion Mathias Tahi ${ }^{1}$, Kouamé François N'guessan ${ }^{1}$, \\ Boubacar Ismaël Kebe ${ }^{1}$, Evelyne Assi ${ }^{1}$, Brigitte Guiraud ${ }^{1}$, \\ Boaké Koné ${ }^{1}$, Nazaire Kouassi ${ }^{3}$, Daouda Koné ${ }^{4}$, \\ Kouassi René Allou ${ }^{1}$, Emmanuelle Muller ${ }^{5}$, Nicodème Zakra ${ }^{1}$ \\ ${ }^{1}$ Cocoa program, National Centre for Agronomic Research (CNRA), BP 808 Divo, Côte d'Ivoire \\ ${ }^{2}$ ICRAF, World Agroforestry Centre \\ ${ }^{3}$ Université Félix Houphouët-Boigny, WAVE-CI, Pôle Scientifique et d'Innovation Bingerville, BP V 34 Abidjan, \\ Côte d'Ivoire \\ ${ }^{4}$ Université Félix Houphouët-Boigny, WASCAL / CEA-CCBAD, Pôle Scientifique et d'Innovation Bingerville \\ ${ }^{5}$ CIRAD, UMR BGPI, 34398 Montpellier, France
}

\begin{abstract}
Cocoa is one of the major cash crop of Cote d'Ivoire. With 1964000 tons in 2018, Côte d'Ivoire is leading the world cocoa beans supply. Unfortunately, this important source of income for the country is under a severe pressure of the Cocoa Swollen Shoot Disease. This disease had been reported for the first time in 1943 in the eastern part of the country. In 2003, important infection areas were reported in the departments of Sinfra and Bouaflé in the Central-West with more than 77.000 ha destroyed. Since that period the disease is reported in several places. But we didn't have a clear idea of all the infected areas. This study aims to study somehow the spread of the disease. The main parameters studied are the incidence and prevalence. The methodological approach consisted in surveys implemented in two steps: 2008-2012 and 2013-2016 on farmer's farms. The study carried out between 2008 and 2012, shows that the CSSD prevalence was $16.37 \%$ with 19 regions infected out of 24 . The disease reaches 83 departments and 40.680 farms. The second phase of the survey held from 2013 to 2016 shows that the prevalence was $19.51 \%$. It help to highlight a strong progression of the disease in the orchard with 7.734 new farms infected in 111 localities divided into 24 regions. Globally the study shows that the incidence of the CSSD in the orchard ranked from $0 \%$ to $76.67 \%$ and the national average is $4.06 \%$. The areas with low incidence cover 85 localities. The areas with moderate incidence are 25. Doba in San Pedro were the area of highest incidence (76.67\%).
\end{abstract}

\section{Introduction}

Côte d'Ivoire is leading world cocoa beans supply with about 1964000 tons tons in 2018 (ICCO, 2018). According to the BCEAO, cocoa represent $15 \%$ to $20 \%$ of GDP (Gross Domestic Product) in Côte d'Ivoire and more than $45 \%$ of the country's export earnings. It employs nearly 600,000 farmers and supports about 6 million people (BCEAO, 2014). Beside this great performance cocoa farming face many constraints. Among these constraints is the Cocoa swollen shoot Disease (CSSD). This disease is nowadays the most devastating disease of cocoa in Côte d'Ivoire. It is a viral disease discovered for the first time in Ghana in 1936 (Steven, 1936, Posnette, 1945). The CSSD causes a severe damage on cocoa trees, leading to a drastic drop in production
(Kouakou, 2011). It is characterized by a red vein banding on young leaves, chlorosis on adult leaves, swelling of shoots and roots (Posnette, 1944, Anon, 1949, Dzahini-Obiatey et al. 2010). The main control measure against this disease consist in cutting of the infected trees, replanting with resistant material, the use of protective barriers involving perennial plants non-host of the virus to surround the replanted area and observation of good agricultural practices (Ollennu, et al. 2005, Dzahini-Obiatey et al., 2005). In Côte d'Ivoire, the CSSD has been reported for the first time in 1943 in Sankadikro and Kongodia in the eastern of the country (Alibert, 1946; Mangenot et al., 1946). Later, infected areas were identified in Daloa, Issia, Soubré and Duékoué in western, Guitry in the south and Adzopé, Aboisso and Grand Bassam

This article is published under the terms of the Creative Commons Attribution License 4.0 Author(s) retain the copyright of this article. Publication rights with Alkhaer Publications. Published at: http://www.ijsciences.com/pub/issue/2020-01/

DOI: 10.18483/ijSci.2203; Online ISSN: 2305-3925; Print ISSN: 2410-4477 
in the south-east (Zelensky, 1947; Meiffrein, 1948; Renaud, 1957). In 2003, massive infection were reported in the departments of Sinfra and Bouaflé in the Marahoué region (Central-West) with more than 77000 ha destroyed (Kébé and N'Guessan, 2003, Kébé et al., 2006, Kouakou, 2011). Today, more than 300,000 ha of the total national area is affected by the disease (Mieu, 2018a). Faced to this alarming situation, the government has launched in 2018 two programs to intensify the uprooting and replanting of orchards infected by the disease. This program of 40 billion FCFA aims to rehabilitate by 2022, 100.000 ha of farm infected. This control plan includes the compensation of producers for 50.000 FCFA per ha destroyed, as well as the distribution of seeds for the replanting of the orchards. The financing of this operation is provided jointly by the CCC and the public-private partnership platform (Mieu, 2018b). But the lack of information on the spread of the virus in the cocoa orchards may jeopardize all the efforts of the government. This study aims to evaluate the incidence and prevalence of swollen shoot in orchard.
The methodological approach consisted in surveys implemented on farmer's farms.

\section{Materials and Methods}

\subsection{CSSD survey on farmers farms}

The inventory of the CSSD infected farms was carried out in two phases from 2008 to 2012 and from 2013 to 2016 by extension agents of the ANADER (Agence Nationale d'Appui au Développement Rural) trained in the recognition of the disease by CNRA scientists. The prospected sites were selected on the presumptions of disease in the producing regions. Total of 23 regions representing more than $80 \%$ of the orchard (Assiri, 2010) and 111 subprefectures were surveyed (Figure 1). The process of the survey was based on interviews with farmers in cocoa producing areas. A questionnaire with three sections was designed for this purpose: Section A: Information on the cocoa farmers, Section B: Description of the cocoa plantation and Section C: Swollen shoot diagnosis

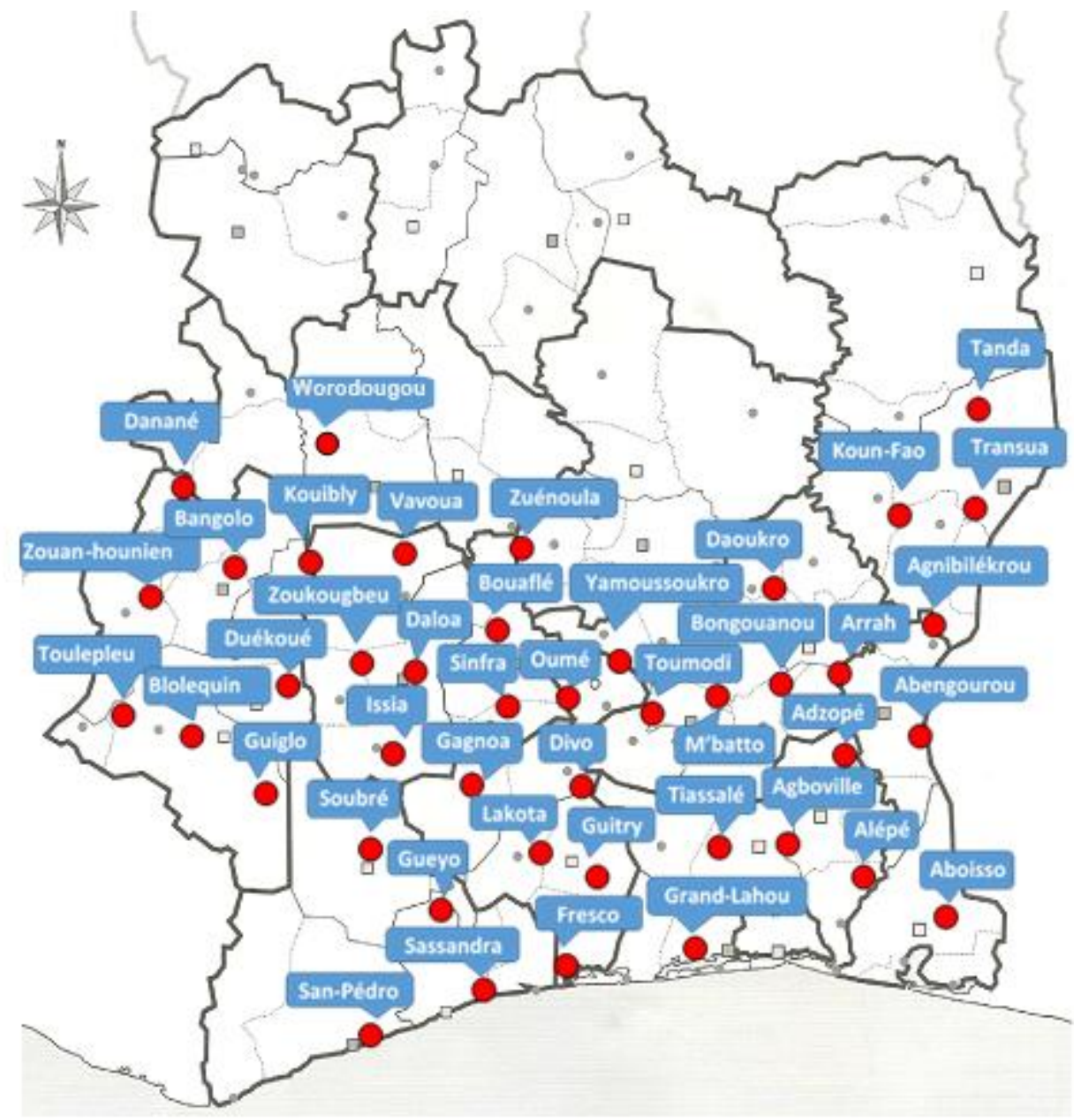

Caption

Sites of CSSD surveys

Figure 1: coverage area by surveys between 2008 and 2016 
2.2. Assessment of prevalence and incidence of CSSD in the orchards

The prevalence of the disease is the percentage of infected farms in the surveyed areas at the time of the study i.e. in 2008 and 2016 (Savary et al., 2006, Fargette, 1987; Thresh and Fargette, 2001):

$f i=$ number of infected farms

$F=$ Total of farms

$P=$ Prevalence

$P=(f i / F) \times 100$

Incidence is the percentage of new cases of the disease in the area during a given period of time. In the context of our study this period run from 2008 to 2016 (Thresh and Fargette, 2001):

$\mathrm{I}=[(\mathrm{fil}-\mathrm{fiO}) / \mathrm{F}] \times 100$

fit $=$ number of infected farms at $\mathrm{t}$ time ;

$\mathrm{t}=$ Date of inspection;

$F=$ Total of farms

$I=$ incidence.

The analysis was essentially descriptive. It aims to present the simple and global results helping to generate a set of questions. This analysis helped to understand the spread of the disease in cocoa farms.
The data generated from the surveys was analysed using Microsoft Excel. For the visualization, data was blast using Microsoft Power Map for Excel and PowerBI software (Dunlop, 2015).

\section{Results}

\subsection{Prevalence of the disease}

The study carried out between 2008 and 2012, covered 24 regions divided into 111 localities, 3.779 villages, 339.633 farmers and 440.180 cocoa farms. It shows that the CSSD was present in 19 regions out of the 23 and 83 departments with 40.680 farms infected. The CSSD prevalence was $16.37 \%$. It show that 16 regions was under $10 \%$ of infections and 3 regions: Haut-Sassandra, Gbôklé and Marahoué was up to $30 \%$ of infection. The second phase of the survey held from 2013 to 2016 shows that the CSSD prevalence was $19.51 \%$. This survey highlights a strong progression of the disease in the orchard with 7.734 new farms infected in 111 localities divided into 23 regions. It shows that 18 regions was under $10 \%$ of infections, three region: Lac, N'zi and Bélier had a rate of infection between 10 and 25, and three: Gbôklé, Haut-Sassandra and Marahoué was up to $30 \%$ of infection (Figure 2).

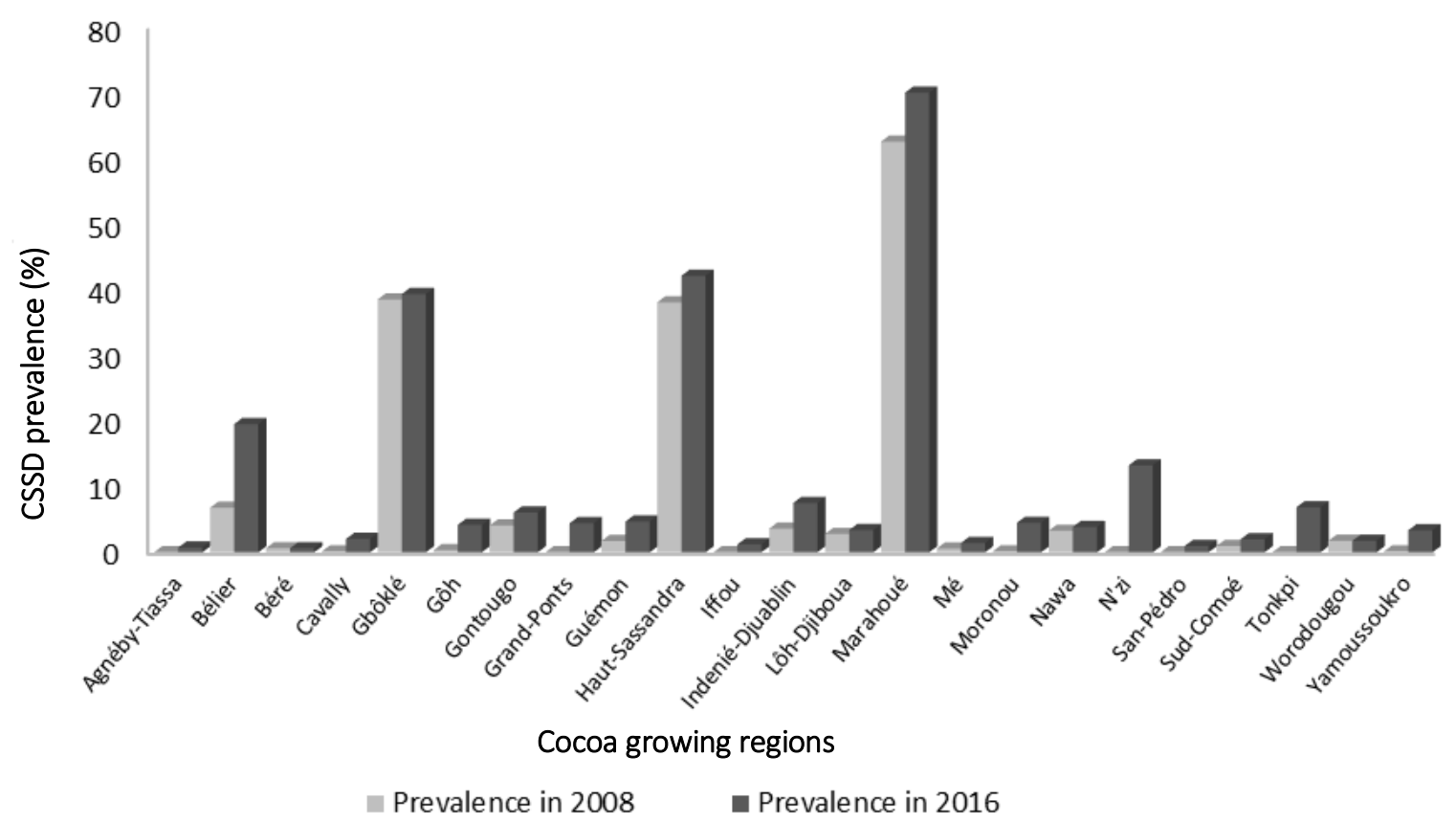

Figure 2: Diagram of the prevalence of the CSSD in the cocoa growing regions of Cote d'Ivoire

Globally based on the data, three infection profiles can considered:

-Low infection regions under 10\%: Agnéby-

Tiassa, Béré, Iffou, Tonkpi, Grand-Pont, San-

Pédro, Cavally, Moronou, Nawa,

Yamoussoukro, Gôh, Mé, , Sud-Comoé,
Guémon, Worodougou, Lôh-Djiboua, IndéniéDjuablin and Gontougo

-Moderate infection regions between 10 and 25\%: N'zi and Bélier

-Massive infection regions more 25\%: Gboklé, Haut-Sassandra and Marahoué 
The analysis at sub-prefecture level shows that the prevalence of the disease ranged from 0.03 to 98.03 $\%$, which allow to define four classes of CSSD prevalence, represented by a thermal amplitude on a map (Figures 3 A et B):

-areas of low attack with a prevalence of less than $10 \%$ are reflected in colour from pale blue to strong blue

-Medium attack areas with a prevalence of between 10 and $25 \%$ green result in colour from pal to strong green

-Strong attack areas with a prevalence of between 25 and $50 \%$ are reflected in colour from pale yellow to strong yellow

-areas of very strong attack with a prevalence higher than $50 \%$ are reflected in colour from orange to red.

In 2012, the areas of low attack covered 58 subprefectures distributed globally in the regions of BasSassandra, Gboklé, Guemon, San Pedro, Cavally, Agneby-Tiassa, Loh-Djiboua, Gontougo, and Indénié-Djuablin with 2.666 farms attacked (Figure $3 \mathrm{~A})$. The areas of medium attack concern 9 subprefectures distributed in the regions of HautSassandra, Marahoué, and Gontougo with the localities Tankéssé and Transua. These areas represent 2.801 plots attacked. The areas of strong attacks and very strong attacks concern the regions of the haut-Sassandra, Marahoué and Gboklé. They are grouped in 16 sub-prefectures and represent respectively 35.213 farms infected.

In 2016, new infected areas were discovered (Figure 3B). These areas are:

-Bongo, Noe, Aboisso-comoe, Assikoi, Alepe, Grand morie, Yakasse-mé, Yakasse-attobrou in the south-east

-Tabagne, Ettrokro, Ebounou, Kouadioblekro, Daoukro, Abengourou, Niable in the east

- Taabo and Yamoussoukro in the central,

-Dairodidizo, Lakota, Serihio and Tonla in the central west,

-Zagne, Blolequin, Binhouye, Zeaglo in the Cavally region in the west

-Gabiadji and Doba in the south west. The prevalence of the CSSD in Doba locality were $76.67 \%$.

Areas of weak attack increased from 58 in 2008 to 76 in 2016 with 4.139 plots attacked. They are distributed in 22 regions. The areas of medium prevalence are 15 and represent 3.932 attacked farms. The number of areas with strong prevalence are 7 and represent 8.096 attacked farms. While the number of areas with very strong attacks count 13 localities distributed and grouped 32.296 farms.

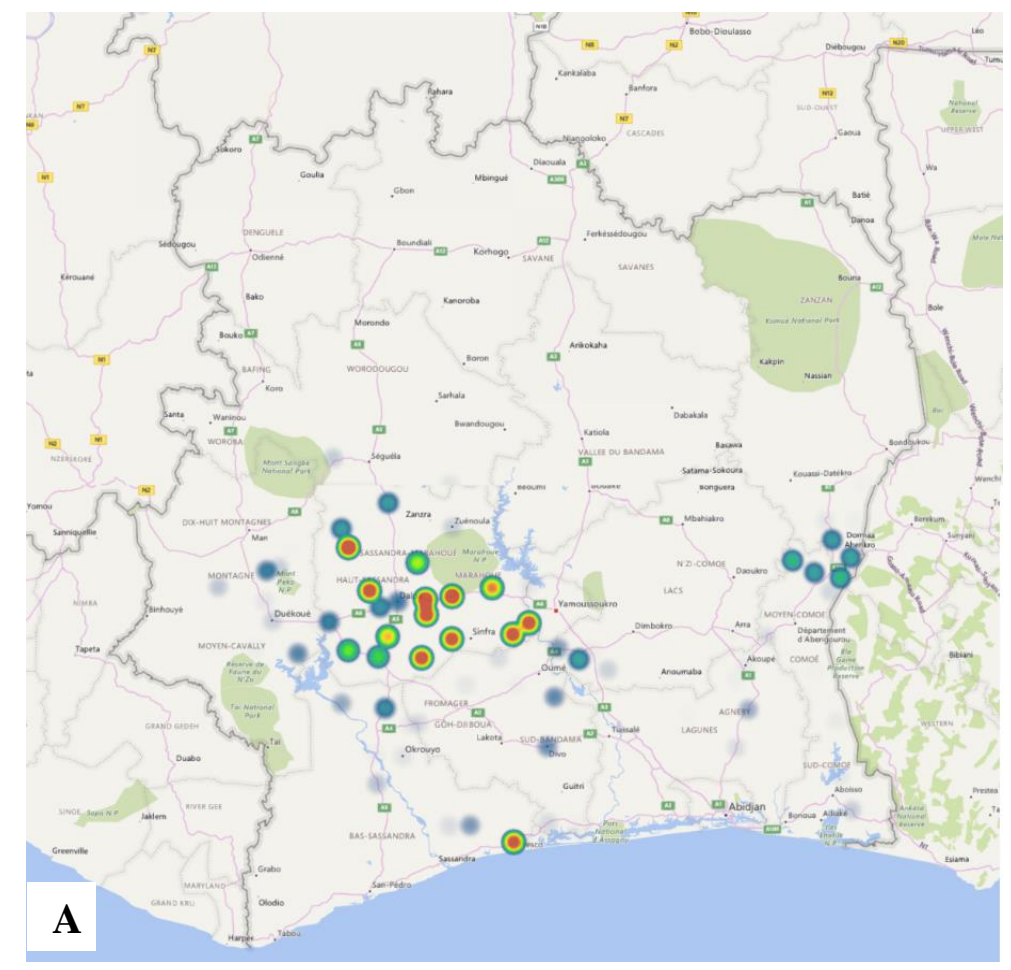




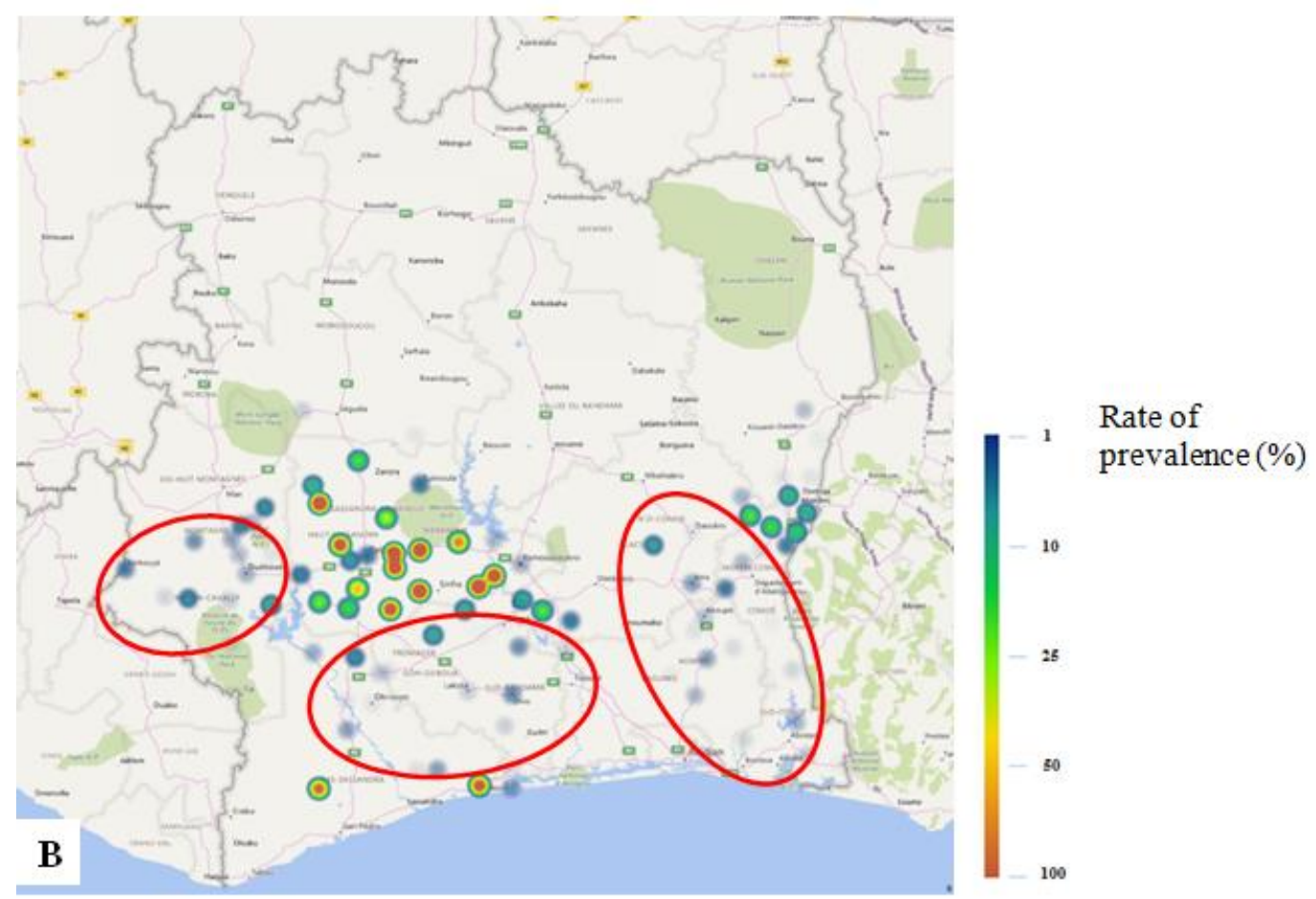

Figure 3: Prevalence of swollen shoot in 2008 (A) and 2016 (B)

The red circles on the map indicate areas where the disease progress

-areas of low attack with a prevalence of less than $10 \%$ are reflected in colour from pale blue to strong blue

-Medium attack areas with a prevalence of between 10 and $25 \%$ green result in colour from pal to strong green

-Strong attack areas with a prevalence of between 25 and $50 \%$ are reflected in colour from pale yellow to strong yellow

-areas of very high attack with a prevalence higher than $50 \%$ are reflected in colour from orange to red.
3.2. Incidence of the CSSD between 2008 and 2016 The study shows that the incidence of CSSD in the orchard ranked from $0 \%$ to $76.67 \%$ and the national average is $4.06 \%$. Three levels of speed of the disease are pointed out:

-Areas with low incidence under 5\%.

- Areas with moderate incidence from 5 to $25 \%$

-Areas of high incidence from 25 to $100 \%$.

The number of areas with low incidence are $85 \mathrm{sub}$ prefectures including 16 new: Grand Bereby, Lauzoua, Yocoboue, Grabo, Sago, Rubino, Toumodi, Kongasso, Okrouyo, Dakpadou, Guiberoua, Guitry, Sify, Buyo, Hiré and Zaïbo. The areas with moderate incidence are 25 and areas of high incidence is Doba in San Pedro were more than 161 infected farms (76.67\%) was reported in between 2013 and 2016 (Figure 4). 


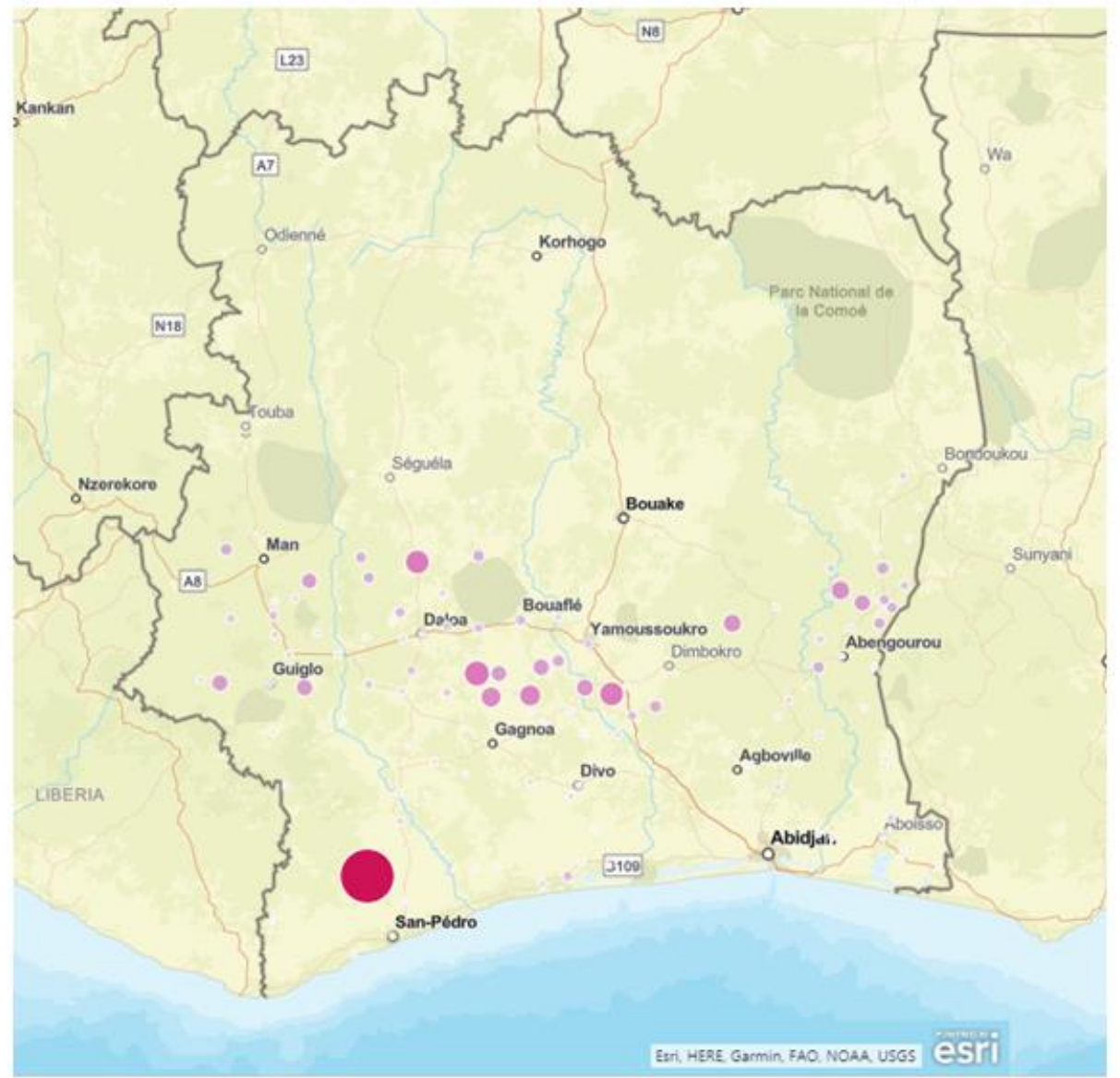

\section{Caption}

Rate of incidence

(\%)

\section{] $0 ; 5]$ \\ ] $5 ; 25]$ \\ $125 ; 1001$}

Figure 4: Rate of incidence of the CSSD from 2008 to 2016

\section{Discussion}

The epidemiological analysis of the CSSD in Côte d'Ivoire cocoa farms from 2008 to 2016 give a view of the distribution of the disease in the orchard. It shows that from 1946 to nowadays the disease has made a clear progress. In fact, between 1946 and 1960, the disease was known to be in the regions of Abengourou, Agnibilékrou, Aboisso, Daloa, Duékoué and Guitry (Basset, 1945, Alibert 1946, Zelensky, 1947 and Meifrein, 1948). To date the disease is almost everywhere in the cocoa producing regions. Massive infection areas are found in the central west and the western part of the country. This large spread of CSSD in these cocoa growing zones could have several explanations. The first may be related to the ignorance of the disease, its symptoms, and control measures (Adegbola, 1971). In fact, at the beginning, in Cote d'Ivoire as well as in the other countries, the disease was assimilated to fungal disease (Ampofo, 1989), insects attacks or lack of nutrient (Adegbola, 1975, Cadbury, 1949) by farmers. So since the year 50s nothing was done like sensitization to enhance farmers' awareness on the swollen shoot disease until 2003 were some cases were reported to research (Kébé and N'guessan, 2003). The second reason is that the first campaigns of combatting the swollen shoot in Cote d'Ivoire were only located in the eastern part of the country (Mangenot, 1946). The western and the central west part were not included. The disease may has started from the untreated foci in these areas. The third is linked to the increasing of crop cultivation in Côte d'Ivoire. In fact, in the 1950s and $1960 \mathrm{~s}$, cocoa was mainly grown in the eastern and eastern regions, with production around 100.000 tons. After 1960, the cocoa boom leads to massive migrations to the western, south-west, and west-west looking for land for cacao (Tano, 2012, Freud et al., 2000).

The studies of the disease incidence show areas with low, moderate, and high rate of incidence. In fact some areas has a low incidence because the disease is at the beginning of infection. There are 16 localities in four cocoa growing regions (Moronou, Iffou, Agneby-Tiassa, Gontougo). These areas have been declared infected with the CSSD in 2015 and are in danger because of the presence of the viral species, CSSTBV which is known to be very aggressive. This species is identified in almost all the cacao growing regions (Muller et al. 2018, Muller and Sackey, 2015, Kouakou et al, 2014,). The areas of low infection include the regions of Mé, Sud-Comoé and IndénieDjuablin where the disease is reported since the year 50s. These areas show a slow incidence maybe 
because of the virus species and the control measures implemented at that time. In fact, the regions of Mé and Sud-Comoé are known to be infected with both species the CSSCEV and the CSSTBV (Kouakou et al. 2014). Maybe the CSSCEV is a mild specie by the date we don't know yet. Also the eradication measures initiated in 1946 in the region of IndéniéDjuablin maybe contributed to reduce the pressure of the disease and slows down its progression (Balleyguier, 1949). Some regions like Marahoué, Haut-Sassandra, and Gboklè where the prevalence of CSSD is highest also show low incidence because almost all the cocoa farms are infected. The regions of Guemon, Tonkpi Cavally, Montagnes and BasSassandra in the west and Southeast considered as the new cocoa growing region (Tano, 2012) are exposed to a fast-growing of infection. In fact the disease may has progress from the Area of Massive Infection like Marahoué, Haut-Sassandra and Gboklè where the prevalence of CSSD is higher than $80 \%$ following a radial spread (Van Der Plank, 1948, 1949; Thresh et al 1988).

Among the factors, the host need to be taken into account as suggested (Shtienberg, 2000). In fact, the disease progress depend on whether the variety is susceptible or resistant (Walters and Hardwick, 2000). In Cote d'Ivoire, the cacao farms are mostly made with all-around, non-improved planting materials and Amelonado while Amelonado is known to be the more susceptible variety to the virus (Adu Ampomah, 1993, Adu-Ampomah et al, 1996, AduAmpomah et al, 2002). The farm practices also may have a part in the disease spread. In fact, Assiri et al. (2009) shows that mostly the cocoa farming profile is monoculture. This farming system enable a continue canopy of inter-locking branches. And as the disease is considered as "crowd" disease (Van Der Plank, 1948, 1949; Thresh et al., 1988) the movement of the mealybug vectors will be easier.

The virus may have emerged and spread to cacao from a few widespread forest tree species known like including Adansonia digitata, Ceiba pentandra, Cola chlamydantha, Cola gigantea var. glabrescens, and Sterculia tragacantha (Posnette, 1950; 1981; Attafuah, 1965).

\section{Acknowledgments}

The authors are grateful to the Conseil du café cacao for founding this research through the FIRCA (Fond Interprofessionnel pour la Recherche et le conseil Agricole), to ANADER for data collecting and ENSEA (Ecole Normal Superieure de statistique et economie Appliquée) for helping in the data analysis.

\section{References Bibliographiques}

1. Abrokwah, F., Dzahini-Obiatey, H., Galyuon, I., Osae-Awuku, F., and Muller, E. 2016. Geographical distribution of cacao swollen shoot virus molecular variability in Ghana. Plant Dis. 100:2011-2017.

2. Adegbola M. O. K., 1975, the reactions of four Nigerian isolates of Cacao Swollen Shoot Virus (CSSD) on the germination and growth of cacao seedlings under different environmental, conditions in proceedings $\mathrm{v}$ international cocoa research conference ibadan, nigeria i_9 september, 1975 Pp 338-343

3. Adegbola M. O. K. 1971, significant developments in the study of the cocoa swollen shoot virus disease, Bull. ent. Soc. Nigeria, 3: 6-18 (1971)

4. Adu-Ampomah Y., 1993, mutation breeding through in vitro culture techniques for resistance to cocoa swollen shoot virus disease, pp9-15

5. Adu Ampomah, Ollenu LL, Padi B., 2002, shoot virus disease resistance in Theobroma cacao L. Breeding and genetics of Cocoa Swollen shoot virus Disease, in journal of the Ghana science association Vol 4 no 22002

6. Adu-Ampomah Y., Adomako B., Owusu G.K. and Ollennu L.A.A, 1996 Breeding for Resistance to the Cocoa Swollen Shoot Virus in Ghana, Internalional Workshop on the Contribution of Disease Besistance to Cocoa Variety improvement, 24th-26th November 1996, Salvador, Brazil pp 173-179

7. Alibert, H., 1946. Note préliminaire sur une nouvelle maladie du cacaoyer le «swollen shoot ». Agronomie Tropicale, Paris, V.1, pp. $34-43$.

8. Ampofo, S. T., 1989. Swollen shoot Control: Review of past and present work. In: Cocoa swollen shoot workshop. Edited by: Michael Manu et E.K. Tetteh. Cocoa Research Institute of Ghana (Ghana Cocoa Board), 33 p.

9. Anon, 1949, Swollen shoot of cocoa, how to recognize and control, Appendix III sessional paper $\mathrm{N}^{\circ} 1$ of march 1948

10. Assiri A. A., 2010. Étude de la régénération cacaoyère en Côte d'Ivoire: Impact des techniques de réhabilitation et de replantation sur le développement et la productivité des vergers de cacaoyer (Theobroma cacao L.) en relation avec l'état du sol. Mémoire de thèse, $170 \mathrm{p}$

11. Assiri A. A., Yoro G. R., Deheuvels O., Kebe B. I., Keli Z. J., Adiko A. et Assa A., Les caractéristiques agronomiques des vergers de cacaoyer (Theobroma cacao L.) en Côte d'Ivoire, Journal of Animal \& Plant Sciences, 2009. Vol. 2, Issue 1: 55 66. ISSN 2071 - 7024; Published on 3rd February 2009 at http://www.biosciences.elewa.org/JAPS

12. Attafuah A., 1965. Occurrence of cocoa viruses in wild plant species in Ghana. In Ghana Journal of Science, Vol. 5, $\mathrm{N}^{\circ} 2$, pp. 97-101

13. Attafuah and Tinsley, 1958

14. BCEAO, 2014, étude monographique sur la filière cacao dans l'UEMOA, Rapport technique

15. Bos L., 1981. Hundred years of koch's postulates and the history of ethiology in plant virus reaserch Neth. J. Pl. Path., 87, p. $91-110$

16. Brunt A. K. et Kenten R. H., 1962. Mechanical Transmission of cocoa swollen shoot virus to and from cocoa and other host Ann. Appl. Biol., 50, p. 749-754

17. Brunt A. K. et Kenten R. H., 1971. Viruses infecting cacao. Rev. Plant Pathol. 50:591-602.

18. Cadbury, 1949, history of the swollen shoot disease on cocoa up to 1949 , report of the cocoa conference held at Grosvenor house, London 30th August- 1st September 1949

19. Cornwell P. B., 1953, mealybug population, distribution and migration In proceedings of the West African international cacao research conference held at the west african cacao research institute tafo, gold coast 12th to 16th December 1953

20. Cornwell P. B., 1958. Movement of vectors virus diseases of cacao in Ghana, bulletin west african cacao research institute tafo, gold coast 
21. Dale W. T. et Attafuah A., 1957. Virus research : the host range of cacao viruses. In Ibid. 1955-56 pp. 281p.

22. Dale W. T., 1962. Disease and pests of cocoa A. virus diseases. In : Agriculture and land use in Ghana. Ed. J B. Wills p. 286-316. Oxford University press, London.

23. Dunlop N. 2015, Beginning Big Data with Power BI and Excel 2013 DOI https://doi.org/10.1007/978-1-4842-0529-7

24. H. Dzahini-Obiatey, G. Akumfi Ameyaw, L.A. Ollennu, 2005, Control of cocoa swollen shoot disease by eradicating infected trees in Ghana: A survey of treated and replanted areas, Crop

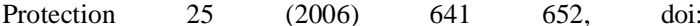
10.1016/j.cropro.2005.09.004

25. Dzahini-Obiatey H. and Fox R. T. V., 2010, Early signs of infection in Cacao swollen shoot virus (CSSV) inoculated cocoa seeds and the discovery of the cotyledons of the resultant plants as rich sources of CSSV, African Journal of Biotechnology Vol. 9 (5), pp. 593-603, 1 February, 2010 Available online at http://www.academicjournals.org/AJB ISSN 1684-5315 @ 2010 Academic Journals

26. Dzahini-Obiatey H.,Owusu D. et Amoah F. M. 2010. Over seventy years of a viral disease of cocoa in Ghana: From researchers' perspective., African Journal of Agricultural Research Vol. 5(7), pp. 476-485, DOI: 10.5897/AJAR09.625

27. Fargette D., 1987. Epidémiologie de la Mosaïque Africaine du Manioc en Côte d'Ivoire; Collection Etude et Thèse, Ed., ORSTOM, 203 p.

28. Hagen L. S., Jacquemond M., Lepingle A., Lot H. et Tepfer M., 1993. Nucleotide sequence and genomic organization of cocoa swollen shoot virus. Virology 196, pp: 619-628.

29. ICCO 2018, Quarterly Bulletin of Cocoa Statistics, Vol. XLIV, No. 3, Cocoa year 2017/18, Published: 31-08-2018, https://www.icco.org/about-us/international-cocoaagreements/cat_view/30-related-documents/46-statisticsproduction.html

30. Kébé B. I. et N'Guessan K. F., 2003. Rapport de la mission de prospection du swollen shoot. 11 - 13 Septembre 2003. C.N.R.A - Divo, 7 p

31. Kébé B. I., N'Guessan K. F., Assiri A A., Aka A. R., N'Guessan W. P., 2011. Guide de la lutte contre la maladie du swollen shoot du cacaoyer en Côte d'Ivoire, Ed FIRCA

32. Kébé I. B., Koffié K., N'Guessan K. F., Assiri A. A., Adiko A., Aké. S., Anno P A., 2006. le swollen shoot en Côte d'Ivoire : situation actuelle et perspectives. In I5th International Cocoa Research Conference. pp 901-922

33. Kouakou K., Kébé BI, Kouassi N, Anno AP, Aké S, Muller E., 2011, Impact de la maladie virale du swollen shoot du cacaoyer sur la production de cacao en milieu paysan à Bazré (Côte d'Ivoire), Journal of Applied Biosciences 43: 2947 2957 ISSN 1997-5902

34. Kouakou K., 2013. Diversité moléculaire du CSSV (Cocoa swollen shoot virus) et épidémiologique de la maladie du swollen shoot du cacaoyer (Theobroma cacao L.) en Côte d'Ivoire, mémoire de thèse, $135 \mathrm{p}$

35. Kouakou K., Kébé B. I., Kouassi N., Anno A. P., Aké S., Muller E., 2011. Impact de la maladie virale du swollen shoot du cacaoyer sur la production de cacao en milieu paysan à Bazré (Côte d'Ivoire), Journal of Applied Biosciences 43: $2947-2957$

36. Legg J. T. et Ollennu L. A. O. 1974. Joint CRIG / Cocoa production division coppicing trials to assess latent virus infection. Rep. Cocoa Res. Inst. Ghana, 1973-1974, 70 p.

37. Lockhart B. E. L., 1990. Evidence for a double-stranded circular DNA genuine in a second group of plant viruses. Phytopathology 80, 127-131.

38. Lot H., Djiekpor Z. and Mireille J., 1991, Characterization of the genome of cacao swollen shoot virus, Journal of General Virology (), 72, 1735-1739. Printed in Great Britain

39. Mangenot G., Alibert H., Basset A., 1946. Sur les caractères du " Swollen-Shoot " en Côte-d'Ivoire. In: Revue internationale de botanique appliquée et d'agriculture tropicale. 26e année, bulletin n ${ }^{\circ} 283-284$, . pp. 173-184

40. Mieu B., 2018a, 29 janvier 2018 à 17h00 | Par Baudelaire Mieu - à Abidjan, Mis à jour le 31 janvier 2018 à $11 \mathrm{~h} 1$
41. Mieu B., 2018b, Cacao : la Côte d'Ivoire et le Ghana unissent leurs forces pour lutter contre le swollen shoot, 24 août 2018 à 17h50 | Par Baudelaire Mieu - envoyé spécial à Pilla (Ghana) et à Manzanouan (Côte d'Ivoire) Mise à jour le 24 août 2018 à $19 \mathrm{~h} 44$

42. Meiffrein, M., 1948. Extrait du rapport annuel 1947 de la division de Phytopathologie du centre de recherche de l'A.O.F. sur le cacaoyer. $\mathrm{N}^{\circ} 188$ / S.C.R.A, 20p.

43. Muller E., Ravel S., Agret C., Abrokwah F., Dzahini-Obiatey H., Galyuon I., Kouakou K., Jeyaseelan EC., Allainguillaume J., Wetten A., 2018. Next generation sequencing elucidates cacao badnavirus diversity and reveals the existence of more than ten viral species. Virus Res. 2018 Jan 15;244:235-251. doi: 10.1016/j.virusres.2017.11.019. Epub 2017 Nov 21.

44. Muller, E. Sackey, S. 2005. Molecular variability analysis of five new complete cacao swollen shoot virus genomic sequences. Arch Virol $150:$ 53-66.

45. Muller E. Jacquot E. and Yot P., 2001, Early detection of cacao swollen shoot virus using the polymerase chain reaction, Journal of Virological Methods 93 (2001) 15-22

46. Ollennu L. A. A., Osei-Bonsu K., Aneani F. and Acheampong K., 2005, preliminary studies of the control of cocoa swollen shoot disease by the use of immune crops as barrier in 14th International Cocoa Conference research, 839-843

47. Owusu C. K., 1972. Acquisition of swollen shoot virus by mealybugs from cocoa plant during the period of talent infection. Ann. Rep. cocoa res. Inst. Ghana, 169-70, 60

48. Partiot M., 1983. Le Swollen shoot du cacaoyer (Theobroma cacao L., sterculiaceae) : Etude de la nature et de l'évolution d'un couple hôte-parasite dans un écosystème tropical. Thèse diplôme de doctorat d'État.

49. Posnette A. F., 1944, the diagnosis of swollen shoot disease of cacao

50. Posnette A. F., 1945, Report and proceeding of the Cocoa Research Conference, Colonial No. 192

51. Posnette A. F. and Strickland A. H., 1948. Technique of insect transmission. Ann. Appl. Biol. 35, 53-63

52. Posnette A. F., Robertson N. F., Todd J. McA, 1950. virus diseases of cacao in West Africa v. alternative host plants from the annals of applied biology, Vol 37, No. 2, pp 229-250, June 1950, West Afriran Cacao Research Institute, Tafo, Gold Coast

53. Posnette, A.F. 1981. The role of wild hosts. Pages $71-78$ in Pests, pathogens, and vegetation, edited by J.M. Thresh. Pitman, London, UK.

54. Raunkiaer C., 1934. The life form of plants and statistical plant geography. Clarendon press, Oxford. $632 \mathrm{p}$.

55. Renaud R., 1957. Distribution of virus disease of cocoa in the Ivory Coast. In: Cocoa Conference, London. Proceeding London, UK: cocoa, chocolate and confectionary alliance, pp:78 - 80.

56. Savary S., Mille B., Rolland B., Lucas P., 2006. Patterns and Management of Crop Multiple Pathosystems. European Journal of Plant Pathology, 123-138.

57. Steven W.F., 1936. - A new disease of cocoa in Gold Coast Gold Coast Farmer, Vol. 7: 122-123.

58. Shtienberg D (2000) Modelling: The basis for rationale disease management. Crop Protection 19: 747-752

59. Tano A. M., 2012. Crise cacaoyère et stratégies des producteurs de la sous-prefecture de Meadji au sud-ouest ivoirien. Economies et finances. Université Toulouse le Mirail - Toulouse II, 2012. Français.

60. Thresh J. M., 1958. The spread of virus disease. In: Technical Bulletin $n^{\circ} 5$. Published on behalf of the West African Cocoa Research Institute. By the Crown Agents for Oversea Governments and Administrations, 4, Millbank, London, S.W.I., 36p.

61. Thresh J. M., 1981. The role of weeds and wild plants in the epidemiology of plant virus disease. In: pests, pathogens and vegetation, Tresh J.M. ed., pitman; London, GB, 53-70.

62. Thresh J.M. et Tinsley W., 1959. The viruses of cacao. Tech. Bull. W. Afr. Cocoa Res. Inst. 7, 1-32 
63. Thresh J.M., et Fargette D., 2001. The epidemiology of African plant viruses: basic principles and concepts in Plant virology in sub-saharan Africa., $111 \mathrm{p}$.

64. Thresh. J .M. , Owusu.G K.; Ollenu A A. (1988a) Cocoa swollen shoot: an archetypal crowd disease Zeitschrift fur Pflanzenkrankheiten und Pllanzenschutz 95 42E-446

65. Thresh , J .M. , Owusu , Cl. K, , Boama h . A. Lockwood, G (1988b) Ghanaian cocoa varieties and swollen shoot virus. Crop Protect 7 2I9-231

66. Tinsley W. et Wharton A. L., 1958. Studies on the host range of viruses from Theobroma Cacao L. Ann. App. Biol. (londre), 46 , pp. 1-6
67. Vander Plank, J.E. (1948) the relation between the size of $\mathrm{f}$ ield and the spreado $f$ plant disease $n$ them. Par $t \mathrm{I}$. Crowd diseases E, mpi rol J. Expl Agric. 16 I34-I42

68. Vander Plank, J.E. (1949) The relationship between the size of fields and the spread of plant disease in them. Part III Examples and discussion ,Empirol J. Expl Agric. 17 I41-I47

69. Zelensky, N., 1947. Partie technique du rapport sur la lutte contre le swollen shoot dans le cercle de Daloa pendant le

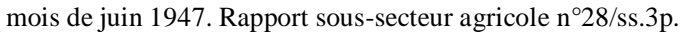

70. Walters KFA and Hardwick NV (2000) Principles of pest and disease management in crop protection. In: Alford DV (ed) Pest and Disease Management Handbook (pp1-18)Blackwell Science,

Oxford 